\title{
ランダムカスケードによる \\ 時空間降水量データの解析 \\ ANALYSES OF TEMPORAL AND SPATIAL PRECIPITATION DATA BY \\ RANDOM CASCADES
}

\author{
葛葉泰久 1 友杉邦雄 $2 \cdot$ 岸井徳雄 3 \\ Yasuhisa KUZUHA, Kunio TOMOSUGI and Tokuo KISHII

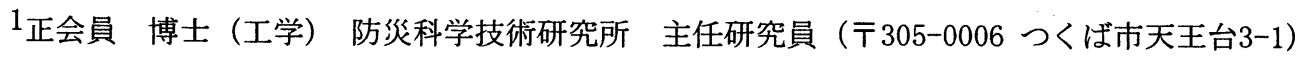 \\ 2 正会員 博士（工学） 京都大学防災研究所 助教授（广611-0011 宇治市五ヶ庄） \\ 3 フェロー 博士 (工学) 防災科学技術研究所 総括主任研究員 (下 305-0006 つくば市天王台3-1)
}

\begin{abstract}
We investigated temporal and spatial precipitation data from the view point of scale invariance or scaling, and examined applicability of random cascades whose generators are defined by $\beta$ model, since random cascades generate data which exhibit fractal behavior. Although $\beta$ model is too simple to simulate daily precipitation time series, 151 of observation points are classified into two groups depending on $p$ value of $\beta$ model; one is a set of observation points along the Japan Sea, and the other is along the Pacific. Regardless of the groups, daily precipitation at 151 observation points exhibit properties of multifractal. Regarding spatial data, we investigated scaling properties using relatively long term's hourly precipitation data. Although each scan exhibits well scaling, the relationship between $p$ value and spatial mean precipitation is not one to one function, if all data are used. If relatively short term's data, namely, data of each precipitation event is used, the relationship is relatively clear and parameters in the relationship depend on events.
\end{abstract}

Key Words: random cascades, temporal and spatial precipitation data, fractal, scaling, scale invariance

\section{1. 序論}

近年, 降水量のフラクタル性に注目した研究，特に降 水量へのランダムカスケードの適用に関する研究が行わ れて来た. Gupta and Waymire' ${ }^{1)}$, Shertzer and Lovejoy ${ }^{2}$ とは異なるタイプ (discreteタイプ) のモデルを降水量 データに適用したが, Over and Gupta ${ }^{3}$ はカスケードジェ ネレーター（2. で詳述する）に にモデルを用いた検討を行

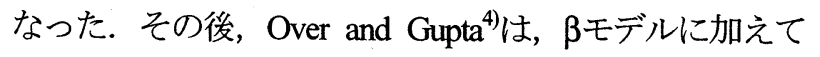
lognormal モデルを適用した. Jothityangkoon et al. ${ }^{5)}$ は, 上 述のランダム変数を発生させる2つのモデルに加え, ジェ ネレーターに決定論的な項を導入した. 国内では, Pathirana et al. ${ }^{6}$ のßモデルとlognormal モデルを用いた研究, 立川らクのジェネレーターに地形依存性を導入した例があ る. また，降水量時系列に関しては, Svensson et al. ${ }^{8)}$ の日 降水量データのフラクタル特性を調べた研究, Pathirana et al. ${ }^{9}$ のランダムカスケードを用いた研究などがある. 著 者らは, ランダムカスケードを用いて, 解像度の粗い GCMデータのダウンスケーリングを行うこと, 平均降水 量から時系列データを発生させることを研究目標として

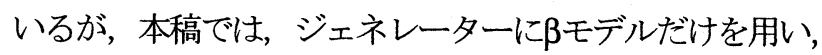
レーダー・アメダス解析データによる空間降水量データ と, 地上気象観測データにランダムカスケードを適用し た解析結果について述べる.

\section{2. 理論と解析方法及びデータ}

スケール不変性, マルチフラクタルの考え方について は，降水に適用されたランダムカスケードを介して考え るとわかりやすい. ここでは, ランダムカスケードによ るシミュレーション手法について, Over and Gupta)を参 考に, 簡単に解説する. 詳細については, 文献3)，4)な どを参照されたい. 図-1の左上（世代 $n=0 ） に$ に示したよう 


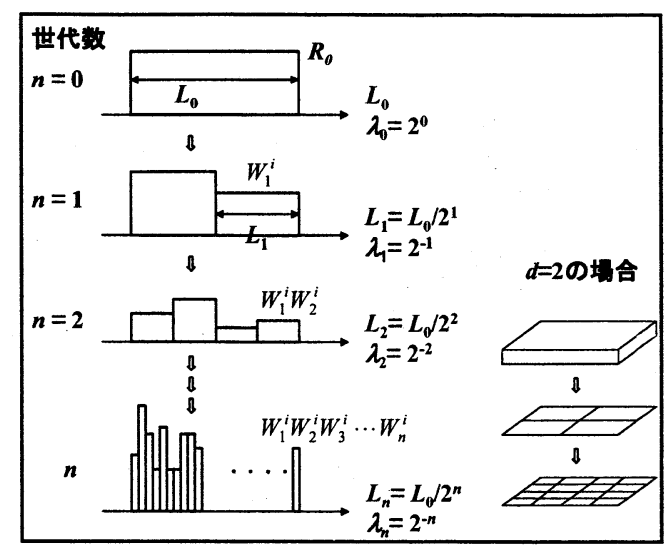

図-1 ランダムカスケードの説明図

に，長さ $L_{0}$ の領域に，単位長さあたり $R_{0}$ の降水があった とする. 素片 $\Delta_{0}$ 上の質量 (降水量) $\mu\left(\Delta_{0}\right)$ は $R_{0} L_{0}$ になる. 次に（世代 $n=1 ） ， L_{0}$ をつに分割し，それぞれの質量を $\mu\left(\Delta_{1}\right)=\left(R_{0} L_{0} / 2\right) \times W_{1}$ で求める. $W$ $E[W]=1$ となる, 互 いに独立な, 同じ確率分布に従う変数 (シミュレーショ ンの際には, 乱数発生させて求める) で，カスケード ジェネレーターという. $n$ 世代分の分割を繰り返した後

（図-1左下），i番目の素片 $\Delta_{n}^{i}$ 上の質量は，次式(1)で表 せる.

$$
\mu\left(\Delta_{n}^{i}\right)=R_{0} L_{0}^{d} b^{-n} \prod_{j=1}^{n} W_{j}^{i}
$$

ここで, $b$ は分岐数, $d$ は次元であり, 今の例, また後 に行う降水量の時系列解析 3 . においては $b=2, d=1$ になる.

4. の空間データの解析においては， $b=4, d=2$ になる（図 1中の右の図参照) . 式(1)中で, $W$ に $i$ ’が付されて いるが，素片 $\Delta_{n}^{i}$ に至る経路上のジェネレーターを意味し ている. なお， $n$ 世代における，素片 $\Delta_{n}^{i}$ の「長さ」 $L_{n}$, 無次元化したスケールパラメータ $\lambda_{n}=L_{n} / L_{0}$ は, $d=1, b=2$ の場合，図中に示したとおりになる.

上記の手続きによって日降水量時系列，レーダー・ア メダスによる空間降水量データが再現できるなら，それ はスケール不変であることを意味する.

ここで, 次の $q$ 次モーメントを定義する.

$$
M_{n}(q)=\sum\left[\mu\left(\Delta_{n}^{i}\right)\right]^{q} \quad-\infty<q<\infty
$$

上式中， $q$ が0以下の場合は，0でない降水量だけを用い る. スケール不変である場合, 次式(3)で（ $n$ が充分大き なところで) 定義される $\tau(q)$ は，スケーリングを用いた 解析において，重要な情報となる.

$$
\tau(q)=\lim _{\lambda_{n} \rightarrow 0} \frac{\log M_{n}(q)}{-\log \lambda_{n}}
$$

$\beta$ モデルは，Wを以下のように定義する.

$$
\begin{array}{ll}
W=0 & \text { (確率 } p \text { で） } \\
W=(1-p)^{-1} & \text { (確率 } 1-p \text { で) }
\end{array}
$$

ここで $p$ は

$$
p=1-b^{-1+\tau(0) / d}
$$
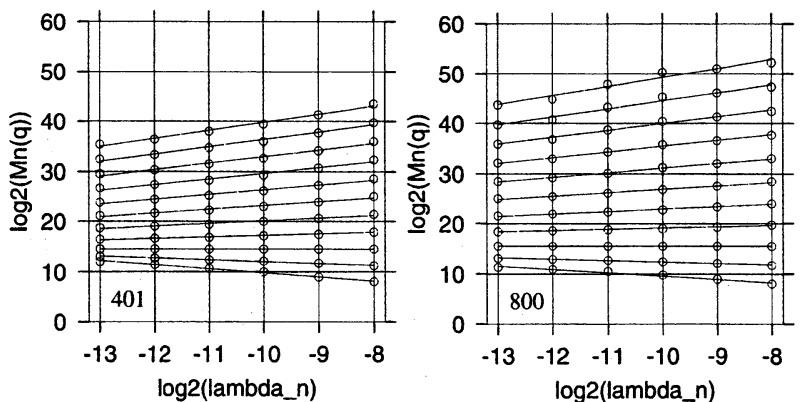

図-2 $\log _{2}\left(\lambda_{n}\right)$ と $\log _{2}\left[M_{n}(q)\right]$ の関係. 左が地点 401 , 右が地点 800のもの.

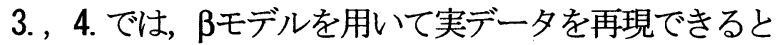
仮定した場合に $p$ がどのような様相を見せるかを通して, 実データへのßモデルの適用の可能性を探り，かつ，関係 諸量の変化傾向から，スケーリングに関する考察を行う. 3. で扱うのは時系列データであり, 図-1 (左) の1次元の 場合に相当し， $L_{0}$ はデータ長 (8192日) に相当する. 4. で扱うのは空間（面）データであり，図-1（右）の2次元 の場合に相当し， $L_{0}$ は領域の一辺 $(320 \mathrm{~km})$ である.

日降水量データとして用いたのは，地上気象観測デー 夕の日降水量データのうち，1961年1月1日から 2000 年12 月31日までのものである．観測点ごと，なるべく新しい データを使うよう，かつ，連続する64日間に観測データ のない日が1日以下になるよう，日降水量時系列データを 作った.「64日」というのは, 後にスケーリングの検討 を行う際， $2^{5}=32$ 日以下のスケールで検討を行うが，準 備的検討では2 6 も検討したからである．なお，連続する 64日に観測データのない日が1日だけあった場合は，その 日の降水量を0とした．この手順で， $2^{13}=8192$ 日分の時 系列データを作成することが可能な151地点を解析対象と した.

空間データとして用いたのは，2001年のレーダー・ア メダス解析雨量のうち，1，2，7,8,9月の日降水量データで ある. 解析領域については，4.で述べる.

\section{3. 時系列データのスケーリング}

\section{（1）時系列データのスケール不変性の確認}

図-2は，地点401（稚内）と地点800（厳原）における， $\log _{2}\left[\lambda_{n}\right](=-n)$ と $\log _{2}\left[M_{n}(q)\right]$ 関係を示したものである. 図中のデータは下から順に, $q=0,0.5,1,1.5,2 \ldots . ., 5$ に対 応し, 各直線はそれぞれの $q$ に対する上記データの線形 回帰直線である. Svensson et $a l^{8)}$ ( は事前検討の結果, $L_{n} \leq$ 32（日）を対象に，両者の関係を調べ，スケール不変性 の有無を論じているが，著者らも， $0 \leq n \leq 13$ についてこ れらの関係を調べた結果, $8 \leq n \leq 13$ の範囲，つまり，同 じく $L_{n} \leq 32$ (日) の範用で検討を行うのが適当と判断し た. 上記2地点以外の地点も含め, 全部で151地点分の同 様の図を検討した結果， $q$ が大きい場合に回帰直線から 


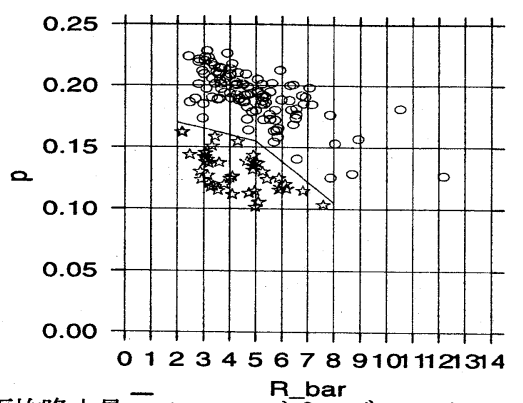

図-3 平均降水量 $\bar{R}(\mathrm{~mm} / \mathrm{day})$ と $\beta$ モデルのパラメータ $p$ 関係

多少離れる傾向があるものの, ほとんどの地点で，デー 夕はおおむね $\log _{2}\left[\lambda_{n}\right](=-n)$ と $\log _{2}\left[M_{n}(q)\right]$ の線形関係を 示していること， 即ちスケールパラメータとモーメント の関係がパワー則で表現可能なことがわかった。ここで, 線形性を有しているかどうかの判断は, それぞれの直線 回帰に対する決定係数が充分大きい（例えば0.9以上）か ぞうかに拠っている．以上より，対象としている期間の 降水量の時系列データが， $8 \leq n \leq 13$ の範囲で，スケール 不変（両者の関係がパワー則で表現可能で，特定のス ケールに依存しない関倸）であることが確認された。

\section{(2) $\beta$ モデルのパラメータ $p$ の評価}

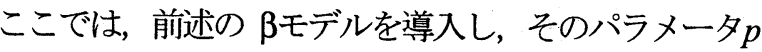
の挙動を調べる. 2. で述べたように, $p$ は $\tau(0)$ 加求めら れる. 寸なわち, (1) で求めた, $\log _{2}\left[\lambda_{n}\right]$ と $\log _{2}\left[M_{n}(0)\right]$ の 関係より $\tau(0)$ を求め, 式(5)から $p$ を求める.

pは, 式(4) からわかるように, 直接的に無降水素片 (降水のない時間またはエリアをこう称す）を規定する ものではなく $\beta$ モデルでシミュレーションを行った場 合に，無降水素片が増殖される，「無降水素片の増殖 率」である.ここでは, 日降水量の時系列データがス ケール不変であり, それが $\beta$ モデルで再現可能と仮定し た場合の「無降水素片の増殖率」 $p$ を求め解析する. 後に

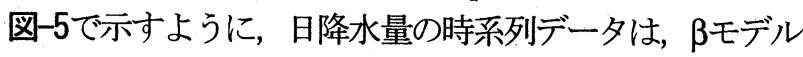
で表せないマルチフラクタル性を示す場合が多い，また，

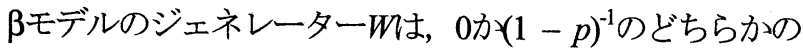
值をとるため, $\beta$ モデルを適用したシミュレーションを行 う際，第1世代から（図-1参照） $L_{0}$ （本論文の場合8192 日），または $L_{0} / 2$ という長期の無降水日が生じてしまう 確率があり，現実的ではない．このように，日降水量の 時系列データに $\beta$ モデルを適用するのは問題があるが， ここでは以下の理由で, $p$ を解析に用いる. すなわち，1) スケールの大きな部分での $\beta$ モデルによる時系列データ のモデル化/生成には無理があるが，それを適用した場 合の $p$ に意味があると考えた. 2) 本論文では, $8 \leq n \leq$ 13 の範囲（タイムスケールは32日以下）て解析を行って おり，このスケールでは，その間に全く降水がない場合

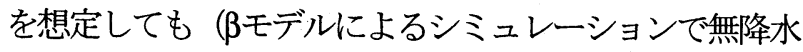
となっても）非現実的ではない.

図-3は，上記の手続きにより求めた $p$ と，8192個の日 降水量から求めた平均日降水量 $\bar{R}(\mathrm{~mm} / \mathrm{day})$ の関係を 151

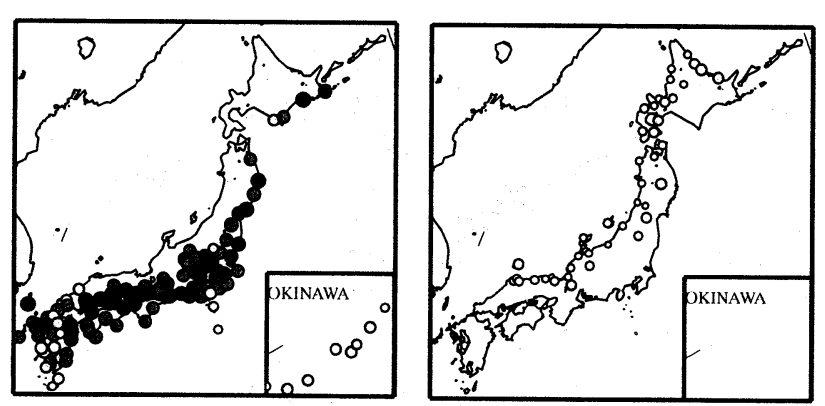

図-4 $\beta$ モデルのパラメータ $p$ の分布. 左の図が「上のグ ループ」, 右が「下のグループ」

地点全部に対して示した図である. 上述のように, $p$ は無 降水素片を直接的に規定するパラメータではないが，そ れが大きければ期間内の無降水日が増え, 平均降水量が 小さくなる傾向があることが予想される. しかし，図-3 を総観的に見ると，両者の関係にそのような傾向はない． そこで, データ群が2つの塊に分化している様相を呈して いることから, 図中に示した折れ線（折れ曲がり点の存 在に意味はない；作図上の都合による）でデー夕群を分 けてみる. 今後, 折れ線の上のデータ群を,「上のグ ルーブ」（○でプロットしたデータ），下のデータ群 （改でプロットしたデータ）を「下のグループ」と称す。

図-4 は, 観測点の位置に $p$. 值を円の半径と円の色 の濃淡で示したものである. すなわち, 円の半径が大き いほどpが大きいことを示す. また，一番色の薄い円は， $p か ゙ 0-0.15$ の範囲にあることを, 続いて色の薄いものか ら， $0.15-0.18 ， 0.18-0.2 ， 0.2$ 以上の範囲にあることを 示す. 図-4より，「上のグループ」の観測点が太平洋側 に分布していること，逆に「下のグループ」の観測点が 日本海側に位置していることがわかる。これらから，太 平洋側，日本海側では，日降水量時系列データの特性に 違いがあることがわかる．太平洋側では，同じ平均日降 水量の日本海側より $p$ が大きく，これは，無降水日が多 い(間欠的である) こと，降水があるときにはその降水 量が日本海側より大きいことを意味する.この特性は, 太平洋側での, 台風をはじめとする降雨の特性, 日本海 側での冬季の降雪の特性が影響していると考える.

\section{（3）マルチフラクタル特性の確認}

Frisch and Prisi10)によると， $\tau(q)$ を $q$ に対してプロットした 曲線が直線になればデータはモノフラクタル，下に凸に なれば（狭義の）マルチフラクタル的特性を有すること になる.（広義の）マルチフラクタルモデルである デルは, $\tau(q)$ と $q$ の関係が線形になるモノフラクタルモデ ルである. ここで，それらの傾向を見るために，両者の 関係をプロットしたのが図-5である. なお，ここでは， $q=5$ に対する前述の決定係数が 0.95 以上のものだけをプ ロットした. 左の図が「上のグループ」に対応し，右の 図が「下のグループ」に対応する. Svensson et al. ${ }^{8}$ は, 地 域の降水の特性により，モノフラクタル的特性を示寸場 

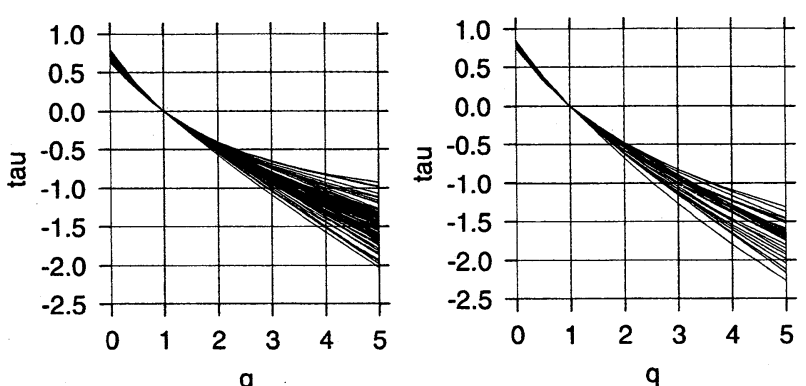

図-5 $\quad q$ とて $(q)$ の関係. 左の図が「上のグル 9 プ」，右が 「下のグループ」

合とマルチフラクタル的特性を示す場合があることを示 している. 図-5から，「上のグループ」と「下のグルー プ」ともマルチフラクタル的特性を示しているが, 平均 的に見て, 前者の方がよりマルチフラクタル性を有して いることが分かる. ただし，図-5 中には $\tau(q)$ と $q$ の関倸 が線形に近いものもあり, それらの地域がいかなる降水 特性を持つかを調べることは今後の課題としたい. また, 上述のように， $\beta$ モデルでは両者の関係が線形となること

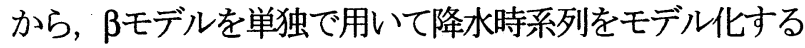
ことは不適当であることがわかる.

\section{4. 空間データのスケーリング}

ここでは，レーダー・アメダスデータを用いて，2次元 のßモデルによる検討を行う. この種の解析は既にOver $e t$ $a l^{3{ }^{34} 4}$ によってなされているが, それらと異なり，降水量 の地域依存性が大きいと考えられる日本の陸域を解析対 象とすること, 特に陸域と海域を比較すること, また, 上記論文では記されていない，解析によって導出される 種々の変量の変化傾向を, 比較的長い期間にわたって観 察することに本論文の意義があると考える.

図-6 に解析領域を示した. 陸域として, 東経 137度〜 141 度, 北緯 34.5度〜 37.7度の領域を, 海域として東経 127.5 度 131.5 度, 北緯 26.5 度 29.7 度の領域を選ん だ. 両領域とも, 空間スケール $L_{0}=320 \mathrm{~km}$ に相当する. また, 冬季と夏季の特性を比較するため, 1, 2, 7, 8, 9月の データを利用した. 本章では, まずそれらの期間を通じ て総観的にデータを見た場合の解析を行い，次に，いく つかの，比較的短い（1日〜数日）期間のデータを用いた 解析を行う.レーダー・アメダスデータは1時間ごとの時 間降水量データであるから, 上記の陸域, 海域ともに, 151 日（5ケ月間） $\times 24$ (時間) $=3624$ シーンの降水場が 得られるわけであるが，レーダーが運用されていなかっ た時間, また, データがあっても降水量のある素片の数 が少なすぎ, 後に述べる回帰計算ができないケースなど を除き，陸域で2302シーン，海域で2717シーンのデータ が得られた. 総観的な解析をする場合はそれらのデータ すべてを用いる. まず(1)で, データを総観的に見て，お もにスケール不変性の有無について論じ, 次に(2)で, イ

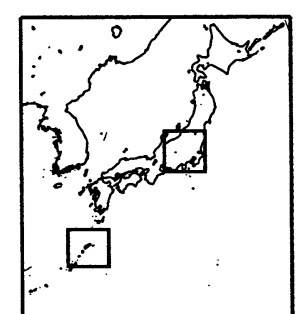

図-6 解析領域。沖縄近辺が「海域」で，関東周辺が「陸域」
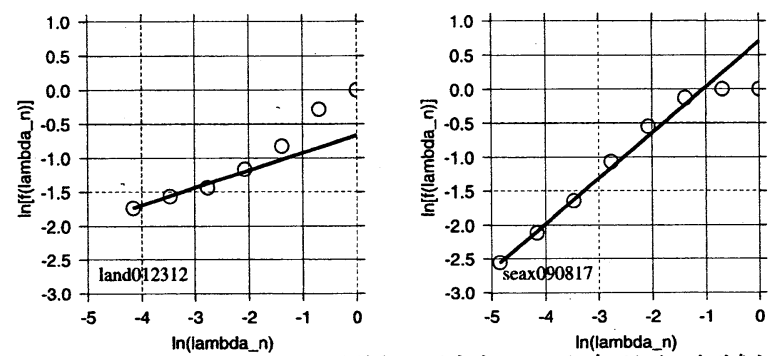

図-7 $\log \left(\lambda_{n}\right)-\log f\left(\lambda_{n}\right)$ 関係. 図中左下の文字列が, 領域と 日時を示している.

ベントごとの降水量データをもとに, $p$ と領域内平均 降水量 $\bar{R}$ の関係を調べ， $\beta$ モデルの適用性を検討寸る.

\section{（1）データを総観的に見た解析}

まず，日降水量データの時系列解析と同じく，陸域， 海域とも，それぞれのシーンについて, $\log \left[\lambda_{n}\right] と \log \left[M_{n}\right.$

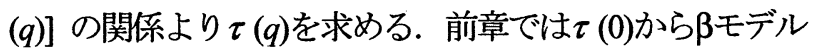
の無降水素片の増殖率 $p$ を求めたが, 以下の説明の都合上, ここでは異なる変量 $f\left(\lambda_{n}\right)$ を用いて $p$ を求める方法3)を解 説する. $f\left(\lambda_{n}\right)$ は降水域の割合 (fractional rainy area) で, 例えば領域内に一つ, 降水量があるピクセルがあれば, $n=0$, すなわち無次元化した空間スケール $\lambda_{0}=1$ では,

$\left(320 \mathrm{~km} \times 320 \mathrm{~km}\right.$ の領域内の降水量は0でなくなり） $f\left(\lambda_{n}\right)$ $=1$ となる. また, その場合, $n$ が最大になると（1,2月に は6, その他で7)，f( $\left.\lambda_{n}\right)$ は， $2^{-6}$ (1,2月)， $2^{-7}$ (7-9月）と いう, 非常に小さな值になる. $\log f\left(\lambda_{n}\right)$ を $\log \left(\lambda_{n}\right)$ に対し てプロットすると, 右上がりの単調増加関数になること が容易にわかるが, その傾きを $s$ とすると, $p$ は, 次式 (6) でも求められる3). すなわち,

$$
p=1-b^{-s / d}
$$

この式で $p$ を求めることと, 前述の式 (5) で求めるこ とは同等である.

図一7は，上記の手順で $p$ を求める際に利用した全シーン に対する $\log \left(\lambda_{n}\right)-\log f\left(\lambda_{n}\right)$ 関係のうち，1月23日12時の陸 域のものと，9月8日17時の海域のものを示した図である. 前者は, 回帰直線の切片が負になるもの, 後者は正にな るものを特に選んだ. 回帰直線を求める際には, Gupta et $a l .{ }^{11}$ に従い, 空間スケール $\left(\lambda_{n}\right)$ ごとのピクセル数により重 み付けをした. それは, 式 (3) が, $n$ の大きなところで 定義されていることに由来する. 文献3)によると，この 切片は, ほぼ $\lim f\left(\lambda_{n}\right) / E\left[f\left(\lambda_{n}\right)\right] k$ 相当し, 切片が正 の場合は，降水域の割合が平均的なものより大きな場合 

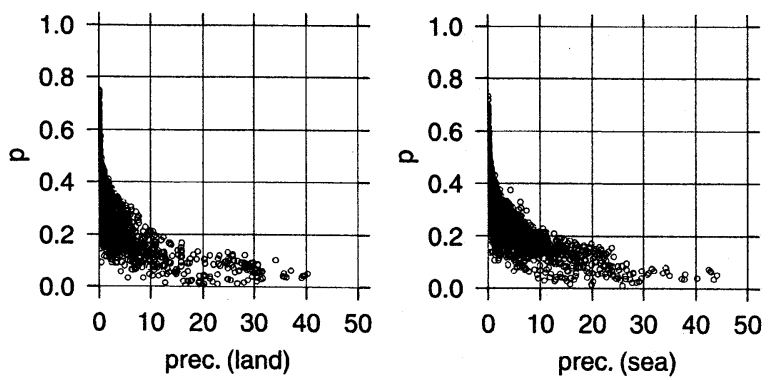

図-8 平均降水量 $(\mathrm{mm})$ と的関係. 左が陸域に関するもの で, 右が海域に関するもの.

に，負の場合は小さな場合に相当するとしている.ここ でいう「平均的」とは, 同じ条件でランダムカスケード による（乱数発生による）シミュレーションを行った際 の平均と考えられ，それ故，実データで切片が正の場合， それが，シミュレーションによる結果のうち「比較的降 水域が多い結果」に相当することを意味する. 文献3)は また，このように切片が正になる場合が多いことを示唆 していろが，著者らが計算した結果，陸域では，切片が 正になる場合と負になる場合が（目視で）ほぼ均等に表 れ，海域では，1，2 月は正負がほとんど均等で，7-9月に 目だって正になることが多いことがわかった．図一の データと回帰直線の関倸より, 切片が正になっている場 合は, $n=1$, 場合によっては $n=2$ に対応する $\log f\left(\lambda_{n}\right)$ が0, すなわち $\left(\lambda_{n}\right)$ が1になっていると思われる. これより，海 域では, 特に7-9月に, $320 \mathrm{~km} \times 320 \mathrm{~km}$ の領域内を4分割し

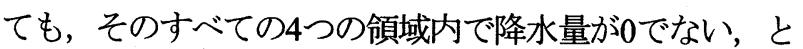
きには16分割しても，そのすべての16個の領域内で降水 量が0でないといった広い範用で同時に降水が起こってい ることが多いことが，上記の現象の理由と考えられる. また，切片が負になる場合も含め, Gupta et al. . $^{1}$ などが指 摘しているように, $100 \mathrm{~km}$ 程度以上のスケールではス ケール不変性が成立せず，それより小さいスケールで， 大きなスケールとは別個のスケール不変的関係を持って いることが，考えられる.

図-8は, $p$ と領域全体の平均降水量の関係を，陸域と海 域を別にして示したものである. 当然ながら, Over et $a l .{ }^{3}$ が示しているように, 一つの関数で近似できるもので はない. ここでは対流性降雨, 前線性降雨など, さまざ まなメカニズムの降水を一様に扱っているからである. すべてのケースについて詳細に，降水メカニズムと対応 させた検討をすべきであるが，次節では，その一部を取 り上げ，比較的短い期間の諸量の変化について考察する.

ここで, 空間スケールが $2.5 \mathrm{~km}$ or $5 \mathrm{~km} \sim 320 \mathrm{~km}$ の範囲 で, スケール不変性が成立しているか研かを検討してお こう. 前述の $\log \left[\lambda_{n}\right]$ と $\log \left[M_{n}(q)\right]$ の関係を, 時系列デー 夕に関する図-2と同じようにプロットし，その直線回帰 式を求める. $q$ の範囲は， $q=0,0.5,1,1.5, \ldots, 4$ とする. そ して, 9個の直線回帰式を求める際に算出された相関倸数 の絶対值の平均值を求める (以下, 簡単のため平均相関 倸数と称す $)$ 。ここで, $\log \left(\lambda_{n}\right)-\log f\left(\lambda_{n}\right)$ 関係を求めた時
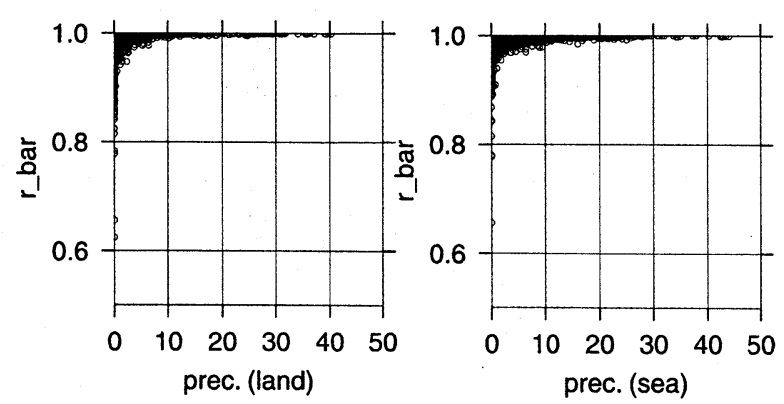

図-9 平均降水量 $(\mathrm{mm})$ と平均相関係数との関係. 左が陸域 に関するもので, 右が海域に関するもの.

のような, 重み付けは行わない，得られた平均相関保数 の時系列を見てみると, 時々低い平均相関係数を示すこ とはあるが，概ね 0.9 以上の高い值を示した. 横軸に領域 内平均降水量, 縦軸に平均相関係数をとり, すべての シーンのデータをプロットしたのが，図-9である．陸域， 海域とも, 平均降水量の極めて小さい場合に相関が悪く なることがあるが，概孙充分な相関があると考えてよい． ただし，ここでは，両対数軸上にプロットした $\lambda_{n} と M_{n}(q)$ を線形近似したのであり，特にnの小さな，すなわち $\lambda_{n}$ の 大きなところでスケール不変性が多少崩れていても，相 関係数に与える影響はさほど大きくない. やはり, 前述 のように, $100 \mathrm{~km}$ 程度のスケールより大きな場合と小さ な場合で，スケール不変的関係が連続していないと考え るべきであろう。

\section{（2）比較的短い期間を対象とした解析}

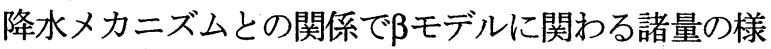
相を論ずるべきではあるが，陸域，海域あわせて約 5,000 シーンのデータがあるので, それは今後の課題とし, こ こでは, 4 つケースを選び, $p$ と平均降水量 $\bar{R}$ の関係 を中心に検討を行う．選んだのは，(a) 9月9日〜11日（陸 域），(b) 7月18日〜20日（海域），(c) 9月27日〜29日

(海域)（d）9月27日〜29日（陸域）である. (a) は，台風 が陸域上を通過した期間，(b) は，停滞前線が九州を横 切っていたが，海域上には前線がなかった期間である. レーダー・アメダスデータを見ると, 南方から強い降雨 域が海域上を北東に進んでいる. (c), (d) は, 停滞前線が 海域の北部にあり, また, 海域の西側に台風が停滞して いた期間である，天気図からは，陸域上に前線はない。 図-10に, $\bar{R}$ の時間変化と, $\bar{R}-p$ の関係を示す. なお, (a), (b), (c), (d) とも, 期間内の平均相関係数は充分に大き かった.

Over et al. は, 2つの論文 ${ }^{33,4)}$ で別の $\bar{R}-p$ 関係の近似 式を提案しているが，両方を比べた結果，文献3)による 下記の近似式の方が若干ではあるが，上記のデータに適 していた.

$$
\left(\frac{\bar{R}}{R_{\max }}\right)^{k}=1-\frac{p}{0.75}
$$

である. 式 (7) 中のパラメータを，表-1に示す. (d) を 除き，それぞれの $k, R_{\text {max }}$ は比較的近い值を示寸が，もち 


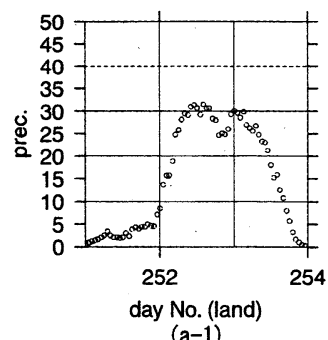

(a-1)

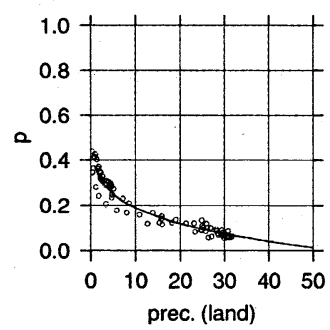

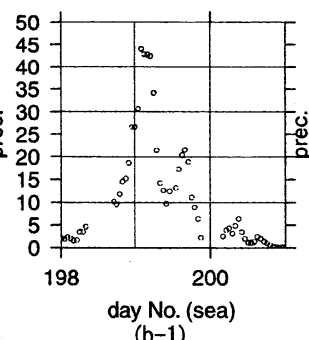

(b-1)

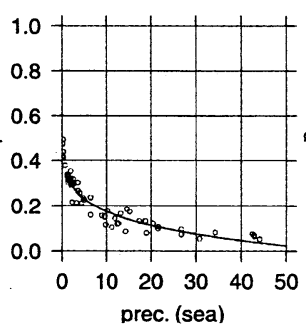

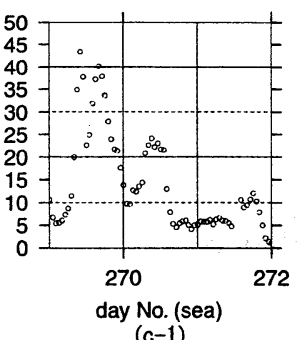

$(c-1)$

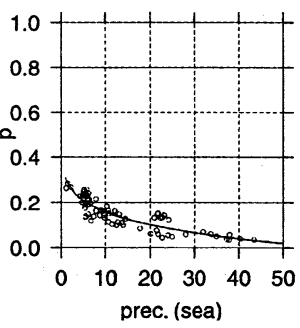

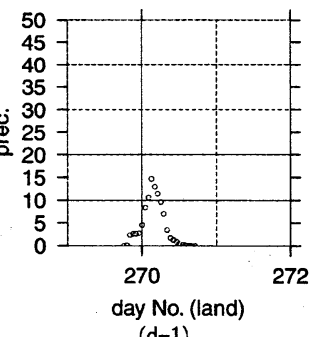

$(d-1)$

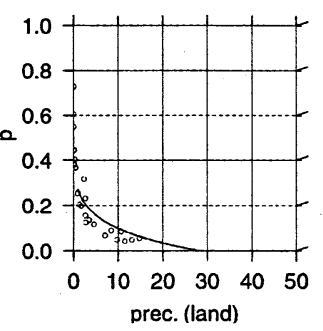

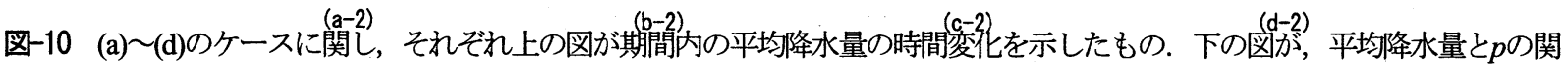
係，近似曲線を示したもの.

表-1 式(7)のパラメータ

\begin{tabular}{ccc} 
& $R_{\max }(\mathrm{mm})$ & $k$ \\
\hline (a) & 55.7 & 0.1666 \\
(b) & 62.1 & 0.1446 \\
(c) & 60.8 & 0.1294 \\
(d) & 28.0 & 0.1357
\end{tabular}

ろんこの4例だけの結果をもって (7) 式の妥当性, パラ メータの類似性を論ずることはできない.

ここにあげた期間以外もいくつかの期間をとって同様 の検討を行ってみたが，天気図で前線が領域内を通過す る場合でも，降水量さえ大きければ（図-9からわかるよ うに）スケール不変性が成立しており，また， $\bar{R}-p$ 関係 については，降水の原因が前線であっても，1つのイベン トをピックアップした場合に1つの曲線でほぼ近似できる 場合が多かった。このあたりは文献3)の記述と多少異な り，さらに詳細な検討が必要である．ただし，台風が領 域内を通過する場合は，イベントのピックアップが容易 であるが，前線が通過する場合などで，期間内にいくつ かの降水量の山がある場合，これを一同にピックアップ すると, $\bar{R}-p$ 関倸が1つの曲線で近似できない場合がある.

\section{5. 結論}

時間・空間降水量データにランダムカスケードを適用

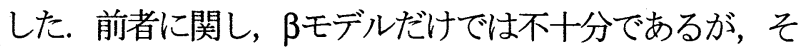
のパラメータ $p$ にり，降水特性が分類できた． 後者に関 し，それぞれの降水イベントに限れば， $\bar{R}-p$ 関係が得ら

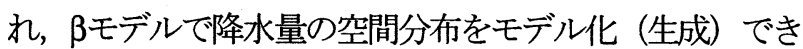
る可能性があることがわかった。

謝辞 : Dr. Thomas M. Overには数々の助言と原稿に対する コメントを戴き，Prof. Vijay K. Guptaには，スケーリング
理論の基礎を教示戴いた。ここに記して謝意を表したい。

\section{参考文献}

1) Gupta, V.K. and ED. Waymire: A statical analisys of mesoscale rainfall as a random cascade, J. Appl. Meteorol., 12, pp.251-267, 1993.

2) Schertzer, D. and S. Lovejoy: Physical modeling and analysis of rain and clouds by anisotropic scaling multiplicative processes, J. Geophys. Res., 92, pp.9693-9714, 1987.

3) Over, T.M. and V.K. Gupta: Statistical analysis of mesoscale rainfall: Dependence of a random cascade generator on large-scale forcing, J. Appl. Meteorol., 33, pp.1526-1542, 1994.

4) Over, T.M. and V.K. Gupta: A space-time theory of mesoscale rainfall using random cascades, J. Geophys. Res.,27, pp.26319-26331, 1996.

5) Jothityangkoon,C., M. Sivapalan and N.R. Viney: Tests of a spacetime model of daily rainfall in southwestern Australia based on nonhomogeneous random cascades, Water Resour. Res., 36, pp.267284, 2000.

6) Pathirana, A., S. Herath and T. Yamada: Preserving spatial heterogeneity in random cascade distributions of spatial rainfall, 水水 学会要旨集, pp.100-101,2002.

7) 立川・寶・日和佐: ランダムカスケードを用いた降雨の模擬 発生に関する研究, 水水学会要旨集, pp.222-223, 2002.

8) Svensson, J., J. Olsson and R. Berndtsson: Multifractal properties of daily rainfall in two different climates, Water Resour. Res., 32, pp.2463-2472, 1996.

9) Pathirana, A., S. Herath and K. Musiake: Scaling rainfall series with a multifractal model, 水工学論文集, 46,pp.295-300, 2001.

10) Frisch, U. and G. Prisi: On the singularity structure of fully developed turbulence, in Turbulence and predictability in geophysical fluid dynamics and climate dynamics, ed. M. Ghil et al., North-Holland, 1985.

(2002. 9. 30受付) 